\title{
PERANCANGAN MODEL WUJUD VISUAL TOKOH PEWAYANGAN DALAM PEMBENTUKAN IDENTITAS DAN WATAK TOKOH SEBAGAI ACUAN DESAIN KARAKTER DALAM KARYA DKV
}

\author{
Toto Haryadi ${ }^{1}$, Khamadi ${ }^{2}$ \\ ${ }^{1,2}$ Dosen Program Studi Desain Komunikasi Visual \\ Universitas Dian Nuswantoro \\ 'haryadi.dinus@gmail.com, ${ }^{2}$ khamadi.dosen@gmail.com
}

\begin{abstract}
Shadow puppets is an arts which is still preserved until now. Recently, shadow puppets can be collaborated with tehcnology through act of revitalization. This is shown by many artworks in the field of Visual Communication Design which adapt shadow puppets. The figures of shadow puppets become main part which is referred for designing of digital artwork, especially "character design". On the other side, revitalization of puppets in form of character design is more concerned with aesthetic aspect than typical identity ones. Whereas, each figure has its own identity and temper which different from each other.

This encourages the researchers to look for relation between visual form with typical identity of puppet figures. The analysis of puppet visual form is required by taking sample based on the classification of the puppet figures, namely: 'denawa', 'punggawa', 'gagahan', 'satria', 'putran', 'putren', 'bayen', 'dagelan', and 'kewanan'. The analysis is based on parameters such as: face expression, position and size of body, clothes, and attributes.
\end{abstract}

Keywords: shadow puppets, revitalization, artwork, character design.

Relevance to Visual Communication Design Practice: The results of analysis are used to create reference or framework, which is implemented for designing of character in accordance with selected figures.

\section{PENDAHULUAN}

Wayang kulit purwa merupakan salah satu kesenian Jawa yang mendapat apresiasi di tingkat internasional sebagai Masterpiece of Oral and Intangible Heritage of Humanity (Susetya, 2007:8). Sebagai pertunjukan, wayang kulit mengandung integrasi seni peran, seni suara, seni musik, seni tutur, seni sastra, seni lukis, seni pahat, serta seni perlambang (Kuning, 2011).

Saat ini, pertunjukan wayang kulit mengalami pergeseran yang awalnya sebagai tuntunan kini lebih dominan sebagai tontonan (Soetarno, 2011:11). Pertunjukan wayang lebih menonjolkan aspek sabetan dan banyolan (Murtiyoso, 2004:79). Penyampaian lakon pewayangan kini bukan lagi menjadi bagian utama, melainkan telah bergeser ke penciptaan efek-efek audio visual dalam pertunjukan, dan yang paling tampak atau dominan yakni sabetan (Darmoko: 2004:84).

Efek visual yang dihasilkan dari sabetan dilakukan menggunakan boneka wayang, yang merupakan wujud perpaduan unsur seni rupa dan seni perlambang. Boneka wayang dibuat dengan visualisasi tertentu serta mengandung makna tertentu. Proporsi wayang kulit digambar menggunakan rasio antara 1:3-1:4 (Haryanto, 1991:32). Unsur seni rupa dalam boneka wayang tampak pada visual wayang yang mengalami perubahan signifikan. Di zaman Hindu wayang kulit digambar realistis mengacu pada relief Candi 
Penataran, sedangkan di zaman Islam, wayang digambar stilasi dekoratif serta bisa digerakkan bagian tangannya. Puncaknya, saat ini terdapat \pm 350 tokoh dengan wujud visual yang berbeda (Haryanto, 1991:26).

Fenomena maraknya penciptaan karya desain komunikasi visual (DKV) bertemakan wayang merupakan wujud upaya kreatif generasi muda yang patut diapresiasi. Hal ini menunjukkan bahwa wayang kulit bisa bersinergi dengan kemajuan teknologi, yang merujuk pada revitalisasi wayang. Salah satu bentuk revitalisasi tersebut yaitu yang dikenal dengan istilah 'desain karakter'.

Di sisi lain, proses desain karakter sebagai upaya revitalisasi wayang kurang memperhatikan esensi penting yang terkandung pada tokoh pewayangan. Setiap perancang memiliki cara dan sudut pandang yang berbeda, sehingga desain karakter yang dihasilkan juga menyampaikan informasi yang berbeda. Padahal, identitas dan watak tokoh wayang menjadi nilai utama sehingga patut dijadikan referensi yang diharapkan bisa menyampaikan nila-nilai tertentu.

Wujud visual tokoh wayang mengandung banyak makna, mulai dari raut wajah hingga kaki. Hal ini berhubungan dengan unsur perlambang, bahwa wayang bukan melambangkan fisik manusia, melainkan melambangkan watak manusia (Bastomi, 1995:9). Setiap tokoh memiliki visualisasi wajah yang berbeda. Perbedaan tersebut bisa dijadikan petunjuk dalam menentukan watak melalui bentuk mata, hidung, mulut, warna muka, serta posisi sikap wajah (Soekatno, 1992:23).

Demi mendukung upaya revitalisasi wayang melalui desain karakter dalam karya DKV, maka diperlukan acuan. Hal ini mendorong peneliti untuk merumuskan framework atau referensi dengan harapan agar hasil akhir desain karakter wayang tidak hanya memiliki tampilan visual yang bagus, tetapi juga menyampaikan identitas dan watak yang khas sesuai dengan tokoh wayang yang diadaptasi. Dari referensi tersebut, nantinya diimplementasikan dalam desain tokoh wayang digital sesuai dengan penggayaan visual dan proporsi yang ditentukan.

\section{Metode Penelitian}

Penelitian dilakukan menggunakan metode kualitatif. Pengumpulan data dilakukan dengan pencarian literatur berupa buku dan jurnal wayang, observasi di sanggar wayang, serta wawancara kepada dalang. Selain itu, penyebaran kuisioner dilakukan untuk mendukung penelitian agar referensi yang dihasilkan dapat diimplementasikan dalam perancangan desain karakter pewayangan sesuai kebutuhan.

\section{Landasan Teori}

\section{Wayang Kulit Dan Tokoh Pewayangan}

Wayang kulit merupakan salah satu dari sekian banyak jenis wayang yang ada di Indonesia. Kesenian wayang terpusat di daerah Jawa, yang tersebar di berbagai daerah sepanjang Jawa Barat hingga Jawa Timur.

Wirastodipuro (Haryadi, et.al 2013:5253) mendefinisikan wayang kulit sebagai suatu pertunjukan yang dilaksanakan oleh masyarakat Jawa dengan media berupa boneka wayang dari kulit kerbau, dimainkan dan dipimpin oleh dalang di depan bentangan kelir yang diterangi blencong, yang mengacu pada adegan dalam suatu cerita dengan musik tradisional gamelan, jika dilihat dari belakang layar akan terlihat bayang-bayang wayang 
sehingga sering disebut wayang bayangbayang. Wayang kulit juga biasa dikenal dengan nama wayang kulit purwa. Istilah 'purwa' berarti: mula-mula atau permulaan, cerita yang bersumber dari kitab Ramayana dan Mahabarata (KBBI, 2008: 1620). Kedua kitab tersebut berasal dari India lalu diadaptasi oleh Prabu Jayabaya dalam Pustaka Raja Purwa, yang telah menjadi rujukan para dalang (Kuning, 2011:15). Dengan kata lain, wayang kulit mendapat pengaruh cukup signifikan dari India baik dari segi lakon (cerita) maupun tokoh serta penokohannya.

Penyampaian lakon (cerita) pada pertunjukan wayang diwujudkan melalui gerakan dan percakapan antar tokoh. Setiap lakon diperankan oleh tokoh wayang yang berbeda sesuai dengan kebutuhan. Sebagai contoh yaitu lakon Parta Krama yang menceritakan pernikahan Arjuna dengan Subadra dengan melibatkan tokoh-tokoh wayang yakni Kresna, Baladewa, Karna, Gatotkaca, dan sebagainya (Ismurdyahwati et.al, 2007).

Penjelasan di atas menunjukkan hubungan yang sangat erat antara tokoh pewayangan dengan lakon. Karena jumlah tokoh wayang sangat banyak, perlu strategi agar bisa mengenal dan mempelajari tokoh wayang secara efektif. Salah satunya yaitu klasifikasi tokoh wayang berdasarkan lakon induk atau lakon besar yakni: 1) Purwacarita; 2) Punakawan; 3) Lokapala; 4) Ramayana; dan 5) Mahabharata (Kuning, 2011).

Lakon Purwacarita membahas perihal asal-usul kehidupan para dewa, dengan tokoh di dalamnya yakni Batara Guru, Batara Wisnu, Batara Indra, dan sebagainya. Punakawan bukan merupakan lakon, melainkan sekumpulan tokoh yang terdiri dari Semar, Gareng, Petruk, dan Bagong,. Lokapala merupakan induk dari lakon Ramayana, dengan tokoh di dalamnya yakni Arjuna Sasrabahu, Sumantri, Parasurama, Sukesi, dan sebagainya. Ramayana merupakan lakon tentang kisah kepahlawanan Rama, dengan tokoh didalamnya meliputi Rama, Sinta, Laksmana, Anoman, Rahwana, dan sebagainya. Terakhir, Mahabarata merupakan lakon konflik Pandawa dengan Kurawa dalam memperebutkan tahta kerajaan, dengan tokoh Pandawa, Kurawa, Kresna, Srikandi, Sengkuni, dan sebagainya.

\section{Wujud Visual Wayang}

Wujud visual wayang menyangkut penerapan seni rupa dan seni perlambang pada hampir seluruh bagian tubuh boneka wayang. Setiap tokoh wayang memiliki wujud visual yang berbeda sesuai dengan klasifikasinya. Boneka wayang kulit yang saat ini digunakan dalam pertunjukan mengalami perubahan bentuk dan wujud visual sejak zaman kerajaan Kediri (pra Majapahit) hingga kerajaan Mataram (Haryanto, 1991:30). Lebih jelasnya bisa dilihat pada tabel 1. 
Tabel 1 Periodisasi Perkembangan Wayang Kulit Sumber: Haryadi (2013:13-17)

\begin{tabular}{|c|c|}
\hline Pembagian Periode & Wujud Visual \\
\hline $\begin{array}{c}\text { Pra Majapahit } \\
( \pm 400-903 \mathrm{M})\end{array}$ \\
$\begin{array}{c}\text { Kerajaan Kediri - } \\
\text { Majapahit } \\
\text { I } 903-1478 \mathrm{M})\end{array}$ \\
$\begin{array}{c}\text { III } \\
\text { Kerajaan Demak - } \\
\text { Mataram - } \\
\text { Penjajahan Belanda } \\
( \pm 1478-1945 \mathrm{M})\end{array}$ & \\
\hline $\begin{array}{c}\text { IV } \\
\text { Pasca kemerdekaan } \\
\pm \text { 1945 - sekarang) }\end{array}$ & \\
\hline
\end{tabular}

Penerapan seni rupa dalam wujud visual wayang dilihat dari bentuk wayang dan sunggingan serta tata warna (Suara Merdeka:2014). Bentuk wayang mencakup ukuran tubuh, penggambaran raut muka, posisi tangan, serta atribut busana. Dilihat dari ukuran tubuh, wujud visual wayang diklasifikasikan dari denawa hingga bayen.

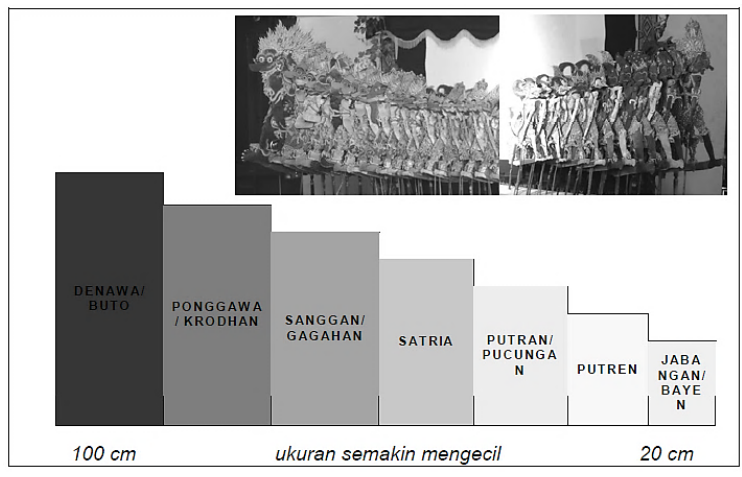

Gambar 1 Perbandingan ukuran wayang Sumber: Pramana, et.al: 2007, 185

Anatomi bagian tubuh wayang juga menyimpang dari logika modern, karena dalam satu wujud tokoh wayang terdapat sudut pandang penggambaran tampak samping, depan, bawah, serta atas. Penyimpangan tersebut lebih jelasnya: 1) wajah (kecuali biji mata), dada, pinggul, lutut, dan betis digambar tampak samping; 2) bola mata, pundak, dan perut digambar tampak depan; dan 3) telapak kaki digambar tampak bawah; dan 4) jari dan kuku pada kaki digambar tampak atas (Haryanto, 1991:32).

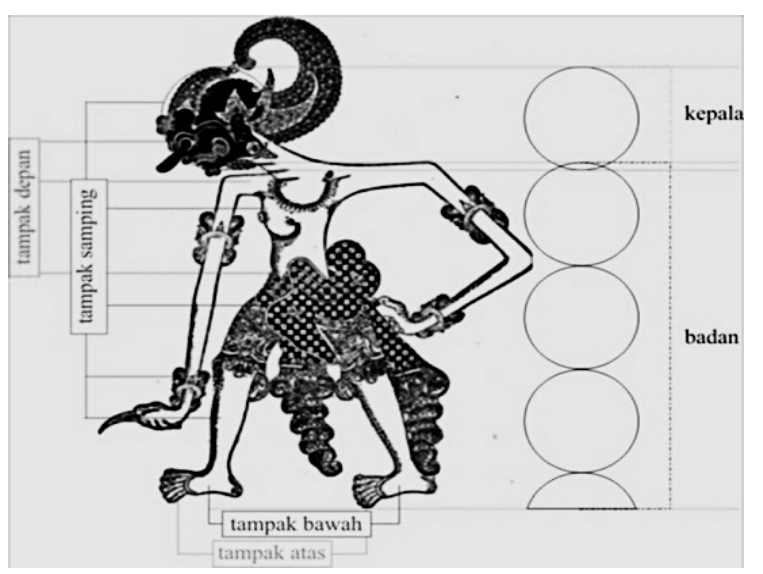

Gambar 2 Contoh proporsi dan anatomi Bima Sumber: Rekonstruksi (Haryadi: 2013, 38)

\section{Bahasa Rupa}

Bahasa rupa atau juga disebut bahasa gambar merupakan suatu cara berkomunikasi lewat medium gambar, yang diungkapkan melalui 
imaji dan tata ungkapan (Ismurdyahwati, et.al, 2007:368). Imaji memiliki dua cakupan, yakni imaji abstrak serta imaji kasat mata. Imaji kasat mata lebih sering digunakan dalam membaca bahasa gambar, yang dibedakan menjadi Isi Wimba dan Cara Wimba (Tabrani, 2005:9). Isi Wimba yaitu objek yang digambar, sedangkan Cara Wimba yaitu cara menggambar objek.

Pengaplikasian ilmu bahasa rupa dalam gambar dua dimensi representatif dibagi menjadi dua sistem, yakni: Naturalis Perspektif Momenopname atau NPM dan Ruang Waktu Datar atau RWD (Tabrani, 2005:131). NPM merupakan sistem temuan barat yang bersifat modern, dilandasi oleh ilmu matematika (perspektif) dan fisika (fotografi), yang digambar dari satu arah, jarak, serta waktu. Objek hasil sistem ini berupa still picture yang dibatasi oleh frame.

Berbeda dengan NPM, RWD didukung teori Relativitas Einstein bahwa ruang dan waktu merupakan satu kesatuan yang tidak bisa dipisahkan. Sistem RWD menggambar objek dari segala arah, jarak, dan waktu. Sistem ini sangat cocok dengan senirupa tradisi Indonesia, yang tidak mementingkan aspek keindahan, melainkan aspek bercerita dengan memanfaatkan cara wimba dan tata ungkapan.

Perbedaan yang cukup mendasar antara sistem NPM dengan RWD yakni penggambaran objek. NPM lebih menitikberatkan pada mimik wajah, sehingga muncul istilah sudut pengambilan gambar seperti: Close Up, Medium Shot, Long Shot, dan sebagainya. Sedangkan RWD lebih menitikberatkan pada gestur, sehingga banyak karya rupa tradisi yang menggambar manusia tampak utuh dari kepala hingga kaki.

\section{Hasil Kuisioner}

Penyebaran kuisioner kepada 60 mahasiswa DKV Udinus bertujuan mengetahui pemahaman mahasiswa terhadap tema pewayangan. Secara lebih detail yakni pengetahuan mahasiswa tentang cerita dan tokoh wayang, karya DKV bertema wayang yang penah dilihat dan/atau dibuat, serta penggayaan visual dan proporsi yang dipilih. Hasil kuisioner adalah sebagai berikut:

Epos / wiracerita wayang apa saja yang Anda ketahui?

\begin{tabular}{|c|l|c|c|}
\hline \multicolumn{2}{|c|}{ Pilihan } & Jumlah & Prosentase \\
\hline a & Mahabharata & 33 & $55,00 \%$ \\
\hline b & Ramayana & 38 & $63,33 \%$ \\
\hline c & Lokapala & 0 & $0,00 \%$ \\
\hline d & Lainnya & 3 & $5,00 \%$ \\
\hline
\end{tabular}

Siapa saja tokoh pewayangan yang Anda ketahui?

\begin{tabular}{|c|l|c|c|}
\hline \multicolumn{2}{|c|}{ Pilihan } & Jumlah & Prosentase \\
\hline a & Yudhistira & 30 & $50,00 \%$ \\
\hline b & Werkudara & 40 & $66,67 \%$ \\
\hline c & Arjuna & 47 & $78,33 \%$ \\
\hline d & Nakula Sadewa & 43 & $71,67 \%$ \\
\hline e & Kresna & 30 & $50,00 \%$ \\
\hline f & Karna & 13 & $21,67 \%$ \\
\hline g & Duryudana & 18 & $30,00 \%$ \\
\hline h & Dursasana & 10 & $16,67 \%$ \\
\hline i & Sengkuni & 15 & $25,00 \%$ \\
\hline j & Baladewa & 9 & $15,00 \%$ \\
\hline k & Drupadi & 18 & $30,00 \%$ \\
\hline $\mathbf{l}$ & Dewi Kunti & 20 & $33,33 \%$ \\
\hline m & Abimanyu & 20 & $33,33 \%$ \\
\hline n & Srikandi & 30 & $50,00 \%$ \\
\hline o & Gatotkaca & 51 & $85,00 \%$ \\
\hline p & Buto Cakil & 35 & $58,33 \%$ \\
\hline q & Rama & 36 & $60,00 \%$ \\
\hline r & Sinta & 36 & $60,00 \%$ \\
\hline s & Anoman & 44 & $73,33 \%$ \\
\hline
\end{tabular}




\begin{tabular}{|c|l|c|c|}
$\mathbf{t}$ & Rahwana & 25 & $41,67 \%$ \\
\hline $\mathbf{u}$ & Semar & 42 & $70,00 \%$ \\
\hline $\mathbf{v}$ & Gareng & 43 & $71,67 \%$ \\
\hline $\mathbf{w}$ & Petruk & 44 & $73,33 \%$ \\
\hline $\mathbf{x}$ & Bagong & 43 & $71,67 \%$ \\
\hline $\mathbf{y}$ & Lainnya & 5 & $8,33 \%$ \\
\hline
\end{tabular}

Pernahkah Anda melihat karya desain komunikasi visual yang bertema wayang?

\begin{tabular}{|c|l|c|c|}
\hline \multicolumn{2}{|c|}{ Pilihan } & Jumlah & Prosentase \\
\hline a & Pernah & 48 & $80,00 \%$ \\
\hline b & Tidak pernah & 11 & $18,33 \%$ \\
\hline
\end{tabular}

Bagaimana sikap Anda terkait semakin maraknya revitalisasi wayang yang diwujudkan dalam bentuk karya desain komunikasi visual?

\begin{tabular}{|c|l|c|c|}
\hline \multicolumn{2}{|c|}{ Pilihan } & Jumlah & Prosentase \\
\hline a & $\begin{array}{l}\text { Sangat } \\
\text { mendukung }\end{array}$ & 54 & $90,00 \%$ \\
\hline b & Biasa saja & 5 & $8,33 \%$ \\
\hline c & $\begin{array}{l}\text { Tidak } \\
\text { mendukung }\end{array}$ & 0 & $0,00 \%$ \\
\hline
\end{tabular}

Pernahkah Anda membuat portfolio / karya desain komunikasi visual bertema wayang?

\begin{tabular}{|c|l|c|c|}
\hline \multicolumn{2}{|c|}{ Pilihan } & Jumlah & Prosentase \\
\hline a & Pernah & 10 & $16,67 \%$ \\
\hline b & Tidak pernah & 50 & $83,33 \%$ \\
\hline
\end{tabular}

Apakah Anda tertarik untuk mengerjakan suatu project / portfolio / karya desain komunikasi visual yang mengadaptasi tema pewayangan sebagai upaya revitalisasi kesenian tradisional?

\begin{tabular}{|c|l|c|c|}
\hline \multicolumn{2}{|c|}{ Pilihan } & Jumlah & Prosentase \\
\hline a & Tertarik & 48 & $80,00 \%$ \\
\hline b & Tidak tertarik & 11 & $18,33 \%$ \\
\hline
\end{tabular}

Jika Anda diminta untuk merevitalisasi wayang ke dalam bidang desain komunikasi visual, karya berupa apa saja yang akan Anda buat?

\begin{tabular}{|c|l|c|c|}
\hline \multicolumn{2}{|c|}{ Pilihan } & Jumlah & Prosentase \\
\hline a & Desain Grafis & 27 & $45,00 \%$ \\
\hline b & Advertising & 20 & $33,33 \%$ \\
\hline c & Multimedia & 17 & $28,33 \%$ \\
\hline d & Animasi & 23 & $38,33 \%$ \\
\hline e & Game & 26 & $43,33 \%$ \\
\hline f & Lainnya & 8 & $13,33 \%$ \\
\hline
\end{tabular}

Berkaitan dengan pertanyaan no. 8, dari ketiga wujud visual karakter wayang Arjuna di bawah ini mana yang Anda pilih?

\begin{tabular}{|c|l|c|c|}
\hline \multicolumn{2}{|c|}{ Pilihan } & Jumlah & Prosentase \\
\hline a & Tradisional & 9 & $15,00 \%$ \\
\hline b & Realis & 25 & $41,67 \%$ \\
\hline c & Eksperimental & 27 & $45,00 \%$ \\
\hline
\end{tabular}

Masih berkaitan dengan pertanyaan sebelumnya, proporsi tubuh desain karakter mana yang menjadi prioritas Anda?

\begin{tabular}{|c|l|c|c|}
\hline \multicolumn{2}{|c|}{ Pilihan } & Jumlah & Prosentase \\
\hline a & Realism & 14 & $23,33 \%$ \\
\hline b & Semi-deformed & 18 & $30,00 \%$ \\
\hline c & Deformed & 27 & $45,00 \%$ \\
\hline d & $\begin{array}{l}\text { Super- } \\
\text { deformed }\end{array}$ & 6 & $10,00 \%$ \\
\hline
\end{tabular}

\section{Analisis Wujud Visual Wayang}

Nama-nama tokoh yang akan dianalisis berpedoman pada hasil kuisioner dan besarnya prosentase. Selain itu juga didasarkan pada klasifikasinya, yakni: 1)denawa diwakili Cakil; 2)punggawa diwakili Bima; 3)gagahan diwakili Gatotkaca; 4)satria diwakili Arjuna; 5)putran diwakili Abimanyu; 6)putren diwakili Sinta; 7)wanara diwakili Anoman; dan 8)dagelan diwakili Petruk. 


\section{Denawa Cakil}

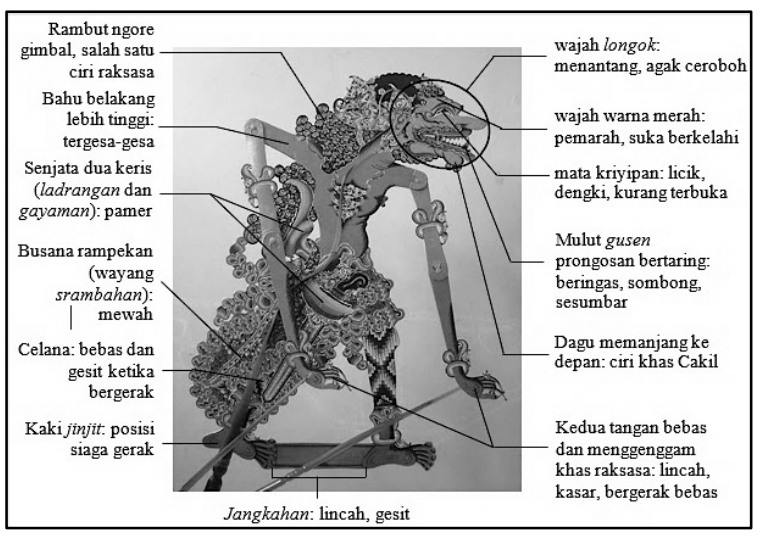

Penjelasan: Cakil sebagai tokoh raksasa yang antagonis, suka menantang, tergesa-gesa, licik, sombong, beringas, lincah, dan gesit. Cakil digunakan dalam perang melawan satria (perang kembang) yang ditantang melalui suaranya yang gegap dan nada tinggi, serta dengan kedua kerisnya. Kecerobohan Cakil diceritakan dalam pertunjukan wayang yakni mati terkena kerisnya sendiri, atau selalu mati ketika bertarung dengan satria yang dijumpainya sehingga berumur pendek. Posisi anjujur (kedua lengan lurus ke bawah) di atas juga menunjukkan karakter Cakil yang bebas bergerak, sesuai dengan kemampuan sabet dalang yang memainkannya.

\section{Punggawa Bima}

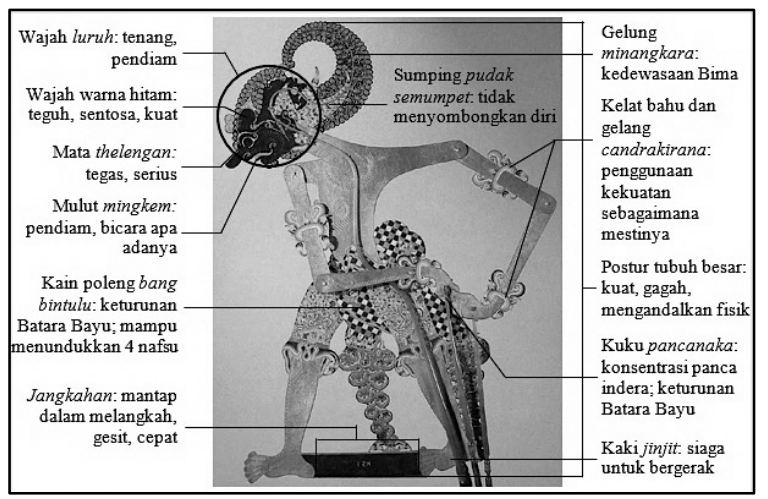

Penjelasan: Bima terkenal dengan kegagahannya. Watak Bima yaitu pendiam, tenang, siaga, tidak gentar, tidak banyak tanya, kuat, gagah, gesit, dewasa, tidak sombong, tetapi mudah emosi dan tidak sabar membasmi kemungkaran dengan senjata terkenalnya yakni Gada Rujakpolo dan kuku pancanaka. Meskipun secara umum punggawa berkarakter banyak tertawa, hal ini tidak berlaku bagi Bima. Gaya bicara Bima yang to the point disampaikan dengan suara besar dan berat (mantap). Posisi mathenteng (lengan depan diletakkan di pinggul) memperkuat watak Bima yang keras kepala dan sulit diajak kompromi. Tidak adanya perhiasan (selain gelang dan kelat bahu) pada tubuh menunjukkan Bima sudah meninggalkan kehidupan duniawi.

\section{Gagahan Gatotkaca}

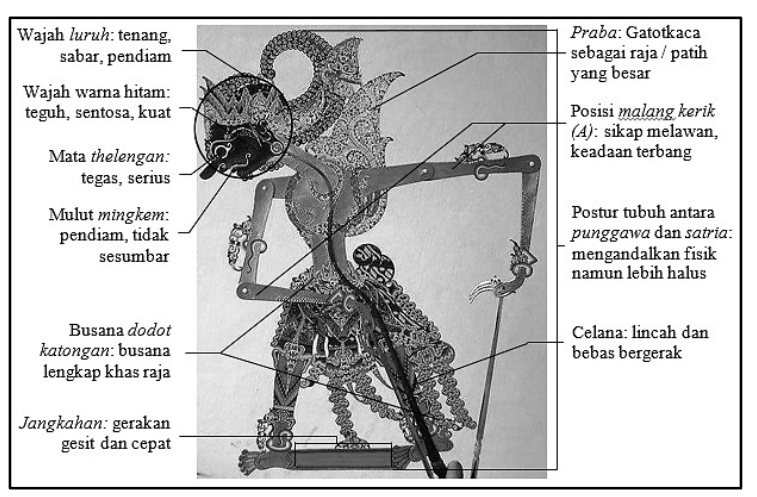

Penjelasan: Sebagai anak Bima, Gatotkaca memiliki ciri fisik hampir sama dengan Bima, khususnya bagian raut muka dan dedeg sehingga beberapa sifat Bima juga dimiliki Gatotkaca, yakni: kuat, berani, pendiam, tenang, dan gesit. Gatotkaca masih memiliki emosi dan cenderung sedikit kasar dibanding satria, namun lebih halus dari tokoh punggawa. Kelebihan yang dimiliki yaitu bisa terbang, dengan posisi siaga malang kerik (A). 


\section{Satria Arjuna}

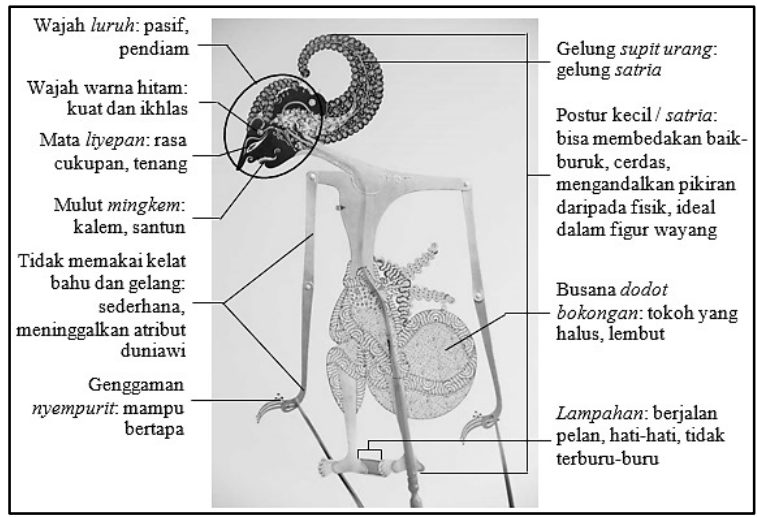

Penjelasan: Arjuna sebagai penengah Pandawa memiliki watak yang berbeda dengan Bima. Arjuna merupakan satria yang pendiam, tenang, sederhana, lemah gemulai, dan cerdas. Sifat lembutnya kadang disalahgunakan untuk memikat wanita, didukung perkataannya yang santun dengan suara besar namun ringan. Kesederhanaan Arjuna tampak pada tidak adanya perhiasan yang terpasang pada lengan, tangan, kaki, dan badan, yang menunjukkan Arjuna sudah meninggalkan kemewahan duniawi.

\section{Putran Abimanyu}

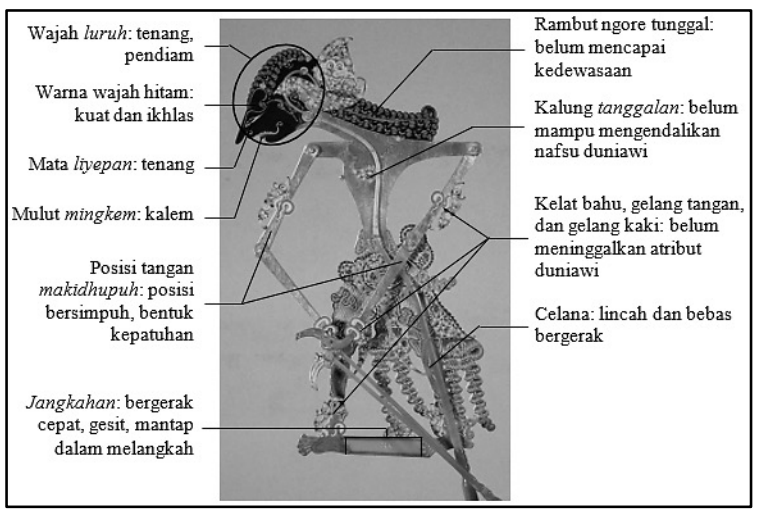

Penjelasan: Abimanyu merupakan anak dari Arjuna dan Subadra. Keberanian Abimanyu tidak diragukan karena juga mewarisi watak Arjuna. Abimanyu menjadi pahlawan dalam Bharatayuda, namun mati di usia 16 tahun saat mematahkan formasi Chakrawyuha (formasi spiral). Abimanyu belum dewasa dan belum bisa meninggalkan nafsu dan kemewahan duniawi, namun di sisi lain tetap tenang, kalem, serta patuh.

\section{Putren Sinta}

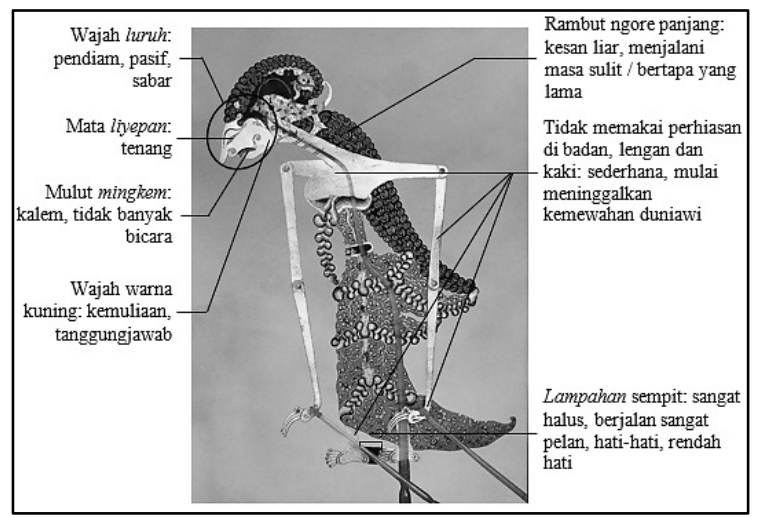

Penjelasan: Sinta merupakan tokoh dalam cerita Ramayana, istri Rama. Sinta dikenal sebagai tokoh yang senantiasa setia mendampingi Rama dalam senang maupun susah. Dari pemaparan di atas Sinta memiliki watak yang sabar, tenang, hati-hati, dan sederhana.

\section{Wanara Anoman}

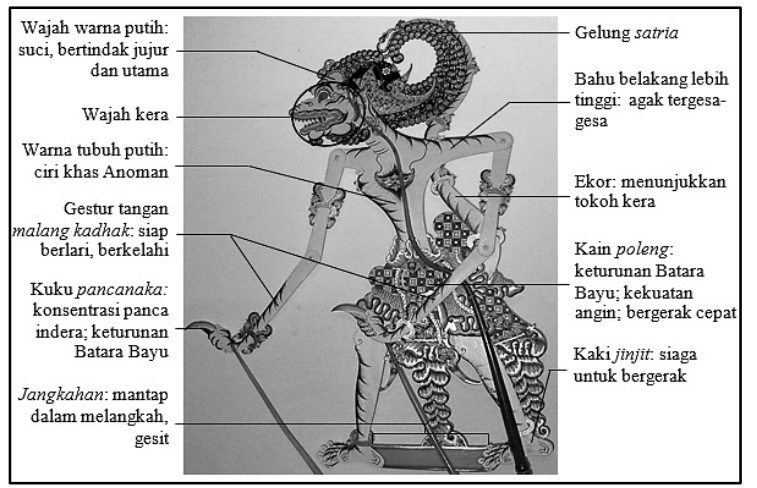

Penjelasan: Sama seperti Sinta, Anoman merupakan tokoh dalam Ramayana, dalam segmen pencarian Sinta yang diculik Rahwana ke negeri Alengka. Anoman juga muncul dalam cerita Mahabharata sebagai saudara tunggal Bayu dengan Bima, yang mana berpengaruh pada kesamaan beberapa 
watak kedua tokoh tersebut yakni: kuat, gesit, bergerak cepat, serta siaga melaksanakan tugas. Anoman juga termasuk tokoh wayang khusus yang berwajah putih, bertubuh putih, sebagai lambang tokoh yang suci, bertindak jujur dan utama.

\section{Dagelan Petruk}

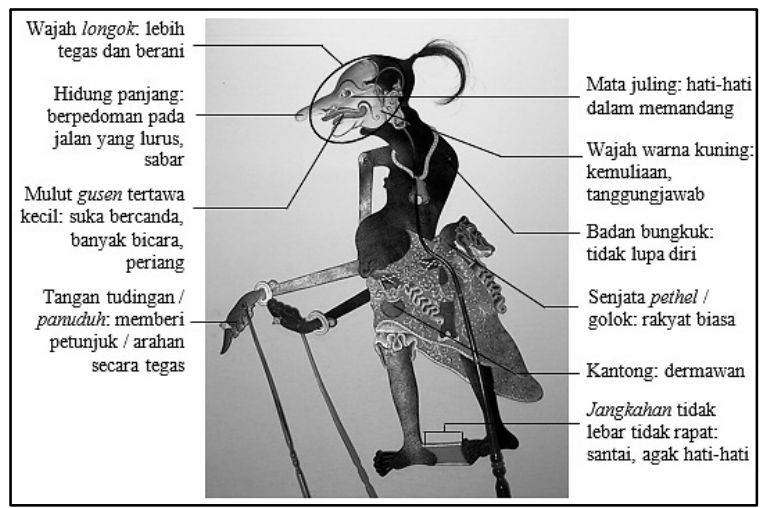

Penjelasan: Petruk merupakan tokoh Punakawan yang terkenal lucu, sama seperti saudaranya. Sebagai abdi, Petruk memiliki watak yang bijaksana, yakni: suka memberi petunjuk, berderma, sabar, berani, namun suka bercanda.

\section{Model Adaptasi Wujud Visual Wayang}

Analisis yang telah dilakukan pada tokoh Cakil, Bima, Gatotkaca, Arjuna, Abimanyu, Sinta, Anoman, dan Petruk merupakan langkah awal dari proses desain karakter. Meskipun peneliti hanya menganalisis delapan tokoh tersebut, sebenarnya inti dari analisis wujud visual yaitu memberikan pemahaman kepada perancang karya ketika akan mengadaptasi tokoh pewayangan. Tanpa bisa menganalisis wujud visual, perancang tidak akan menemukan identitas dan watak khas dari tokoh yang akan diadaptasi. Dari analisis kedelapan tokoh tersebut, akan dibuat tabulasi sebagai bentuk framework atau model (kerangka acuan) yang bisa diadaptasi untuk membuat karakter. 


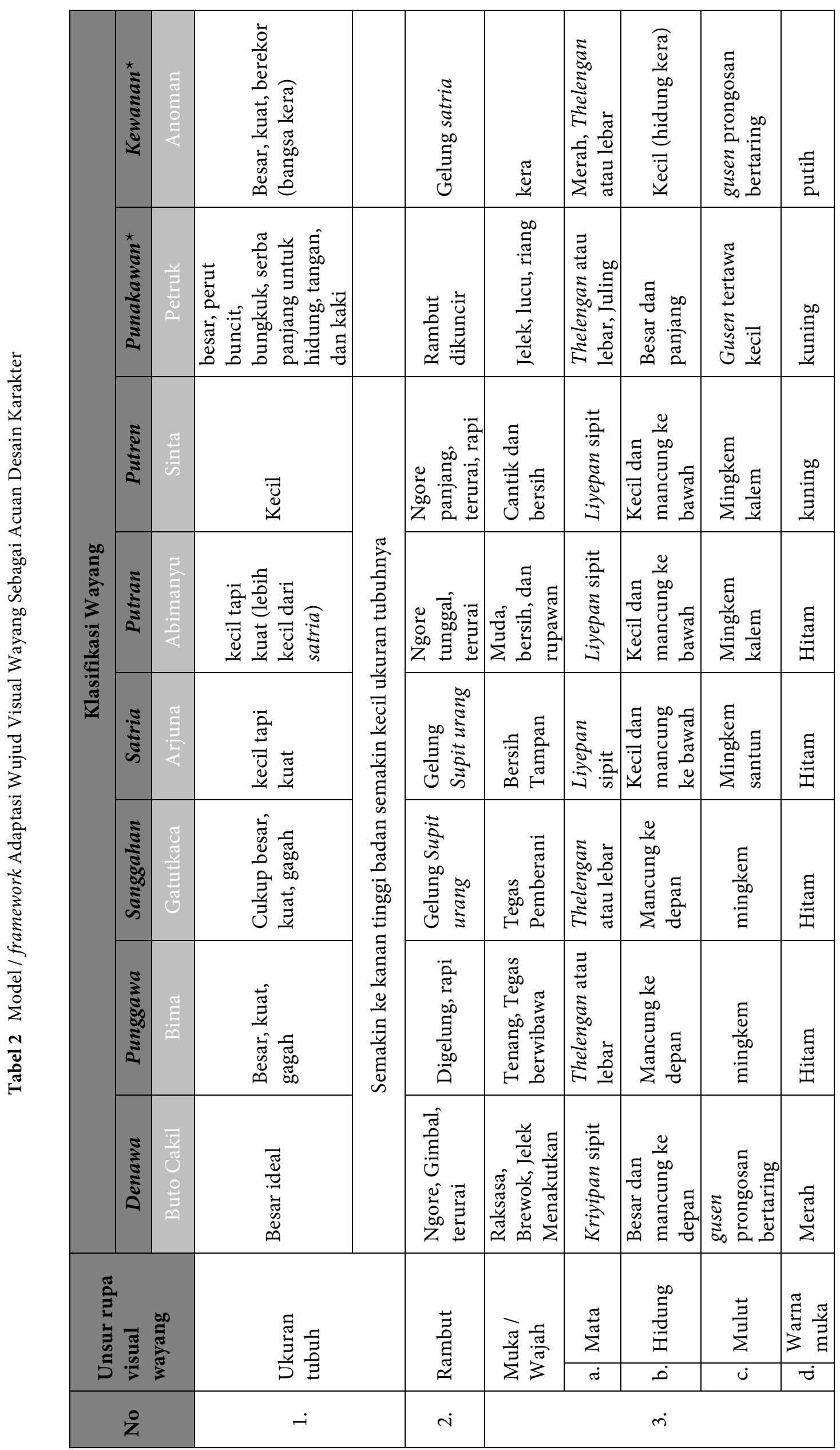




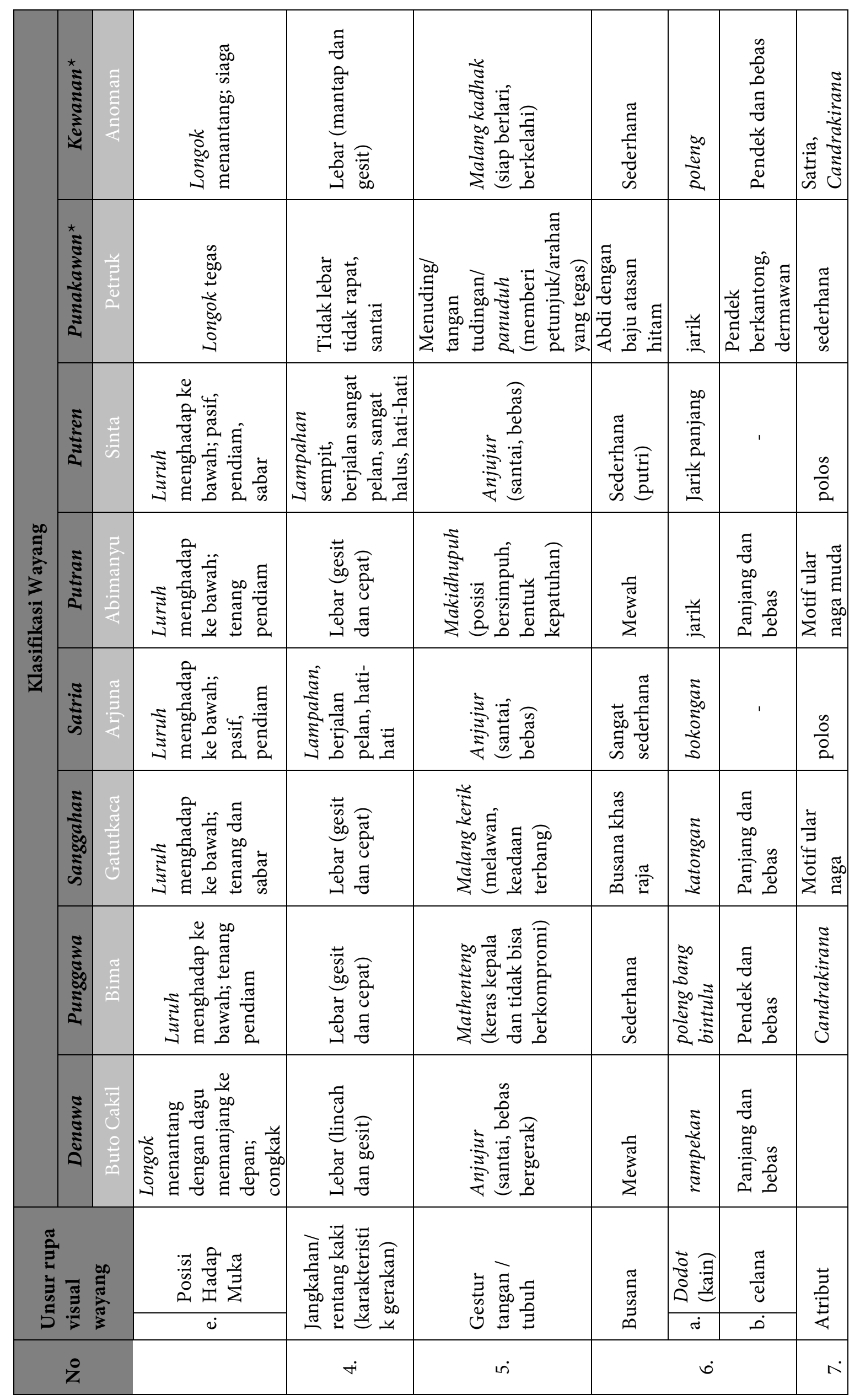

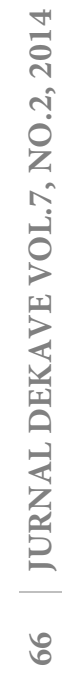




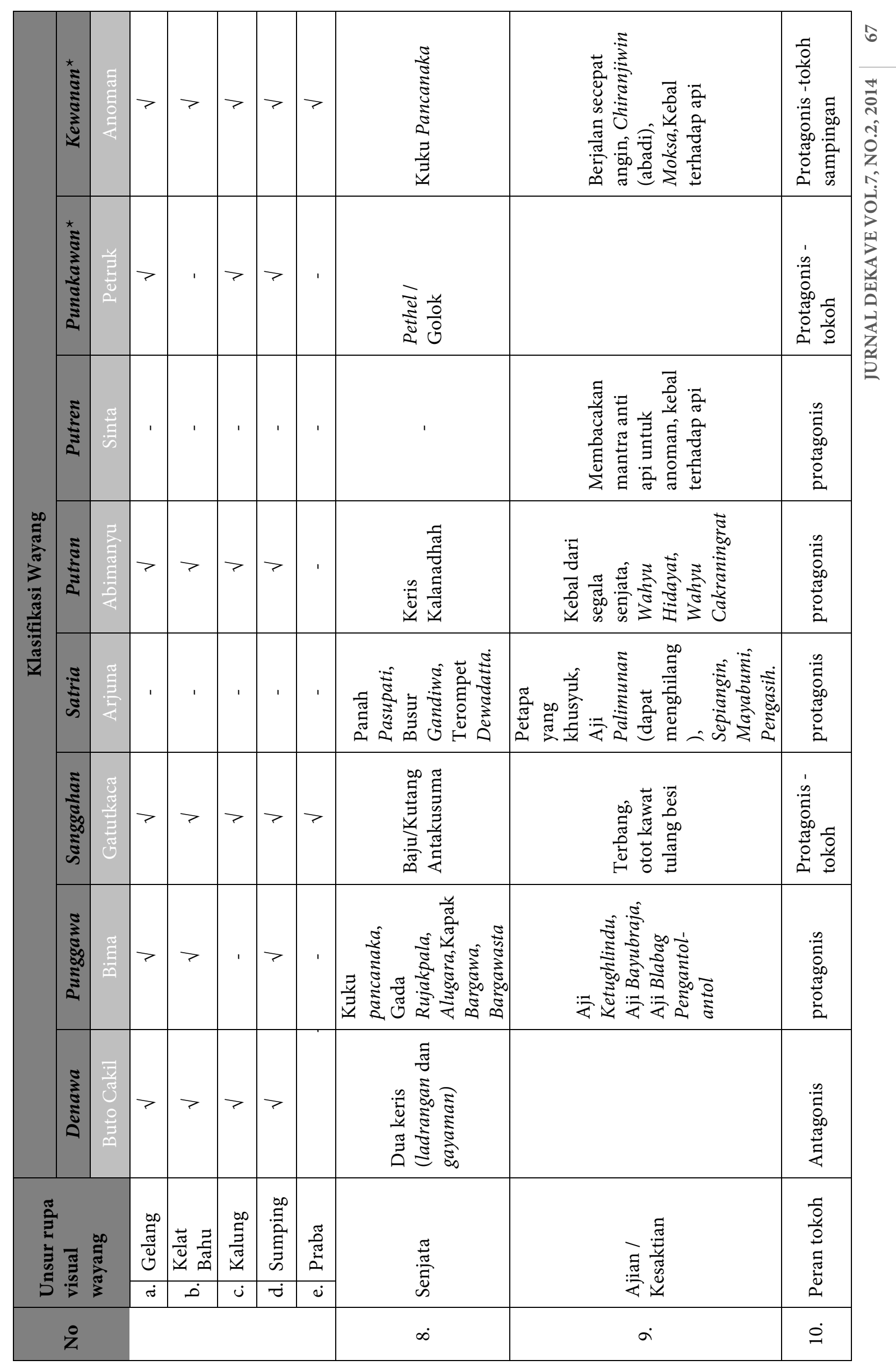



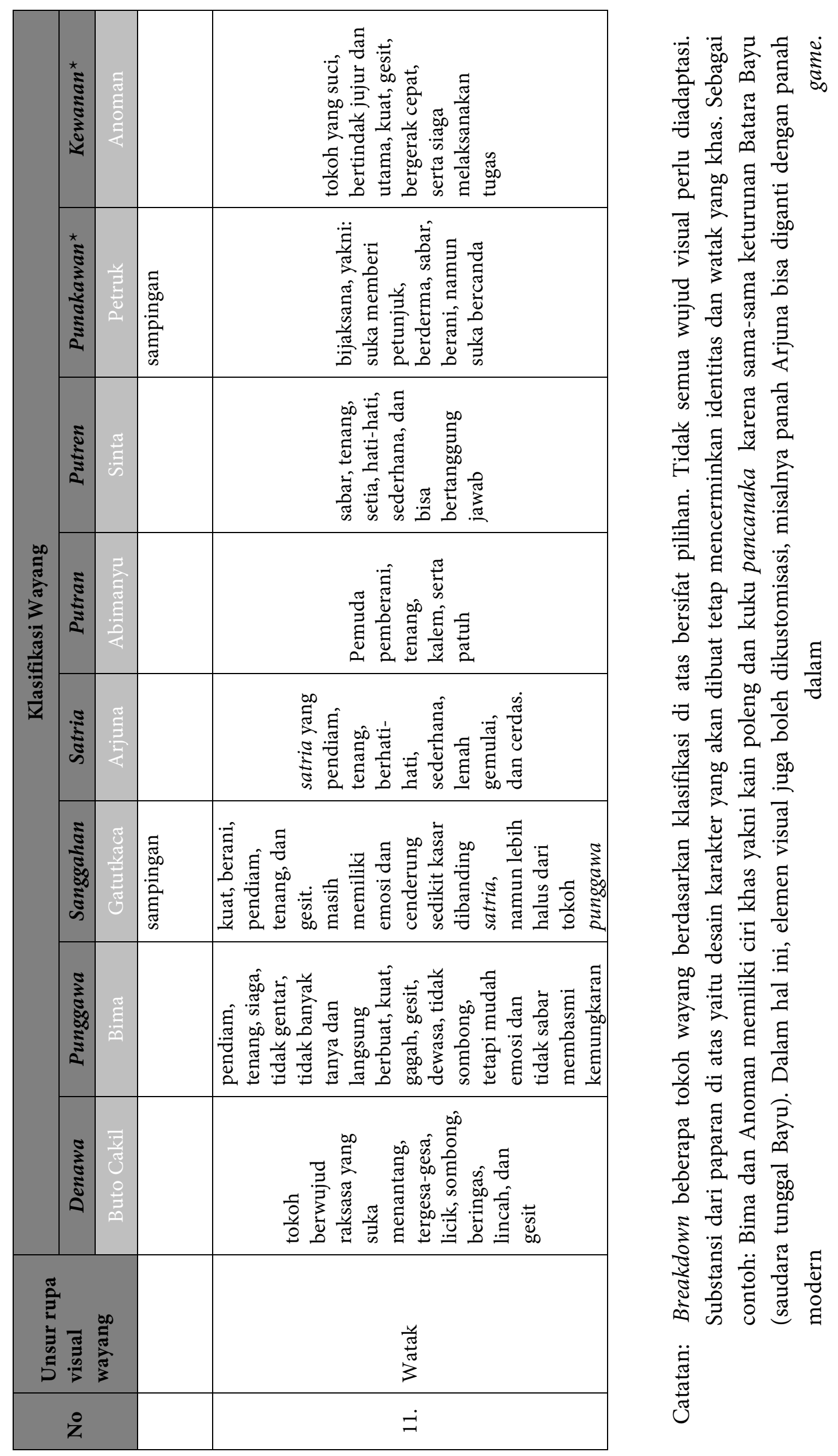

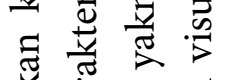
壱

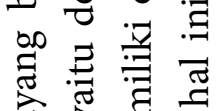
趂灵 उ 爷

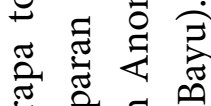
芯 芯

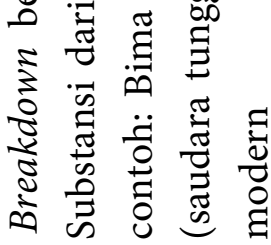
菾 
Model Skema Implementasi Wujud Visual Wayang ke dalam Desain Karakter

Model wujud visual wayang berupa tabel 2 akan diadaptasi untuk proses desain karakter. Langkah awal yang perlu dilakukan yakni menentukan cerita wayang atau tokoh wayang yang akan diangkat, karena setiap tokoh menyampaikan pesan yang berbeda satu sama lain. Setelah itu, breakdown tokoh yang telah dipilih perlu dilakukan, untuk menentukan identitas dan watak yang khas dari tokoh tersebut. Hal ini merupakan aspek perlambang sebagai pedoman dalam membangun kepribadian tokoh. Bagian yang tidak boleh dilewatkan yakni transformasi dari bahasa rupa wayang (RWD) ke bahasa rupa desain karakter (NPM) untuk menyelaraskan sudut penggambaran tokoh dari satu arah. Berikutnya yakni aspek estetika desain khususnya penentuan gaya visual dan proporsi desain karakter, apakah mengadaptasi gaya Indonesia, barat, Jepang, atau gaya eksperimental lain dengan ukuran tubuh realis, semi deformasi, deformasi, atau bahkan super deformasi. Semua penjelasan tersebut akan dibuat model skema implementasi wujud visual wayang ke dalam desain karakter. 


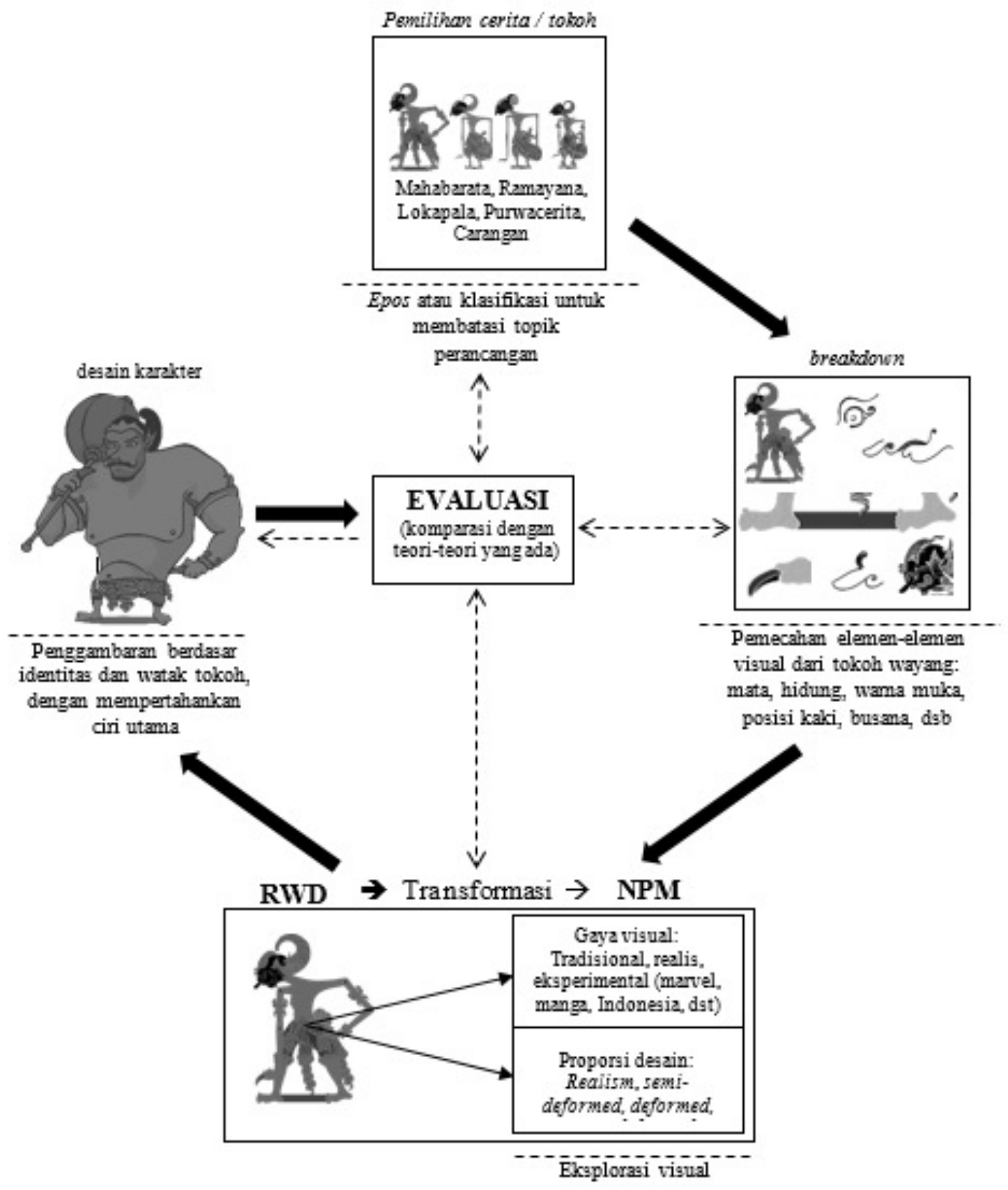

Gambar 3 Model Skema Implementasi Wujud Visual Wayang ke dalam Desain Karakter 


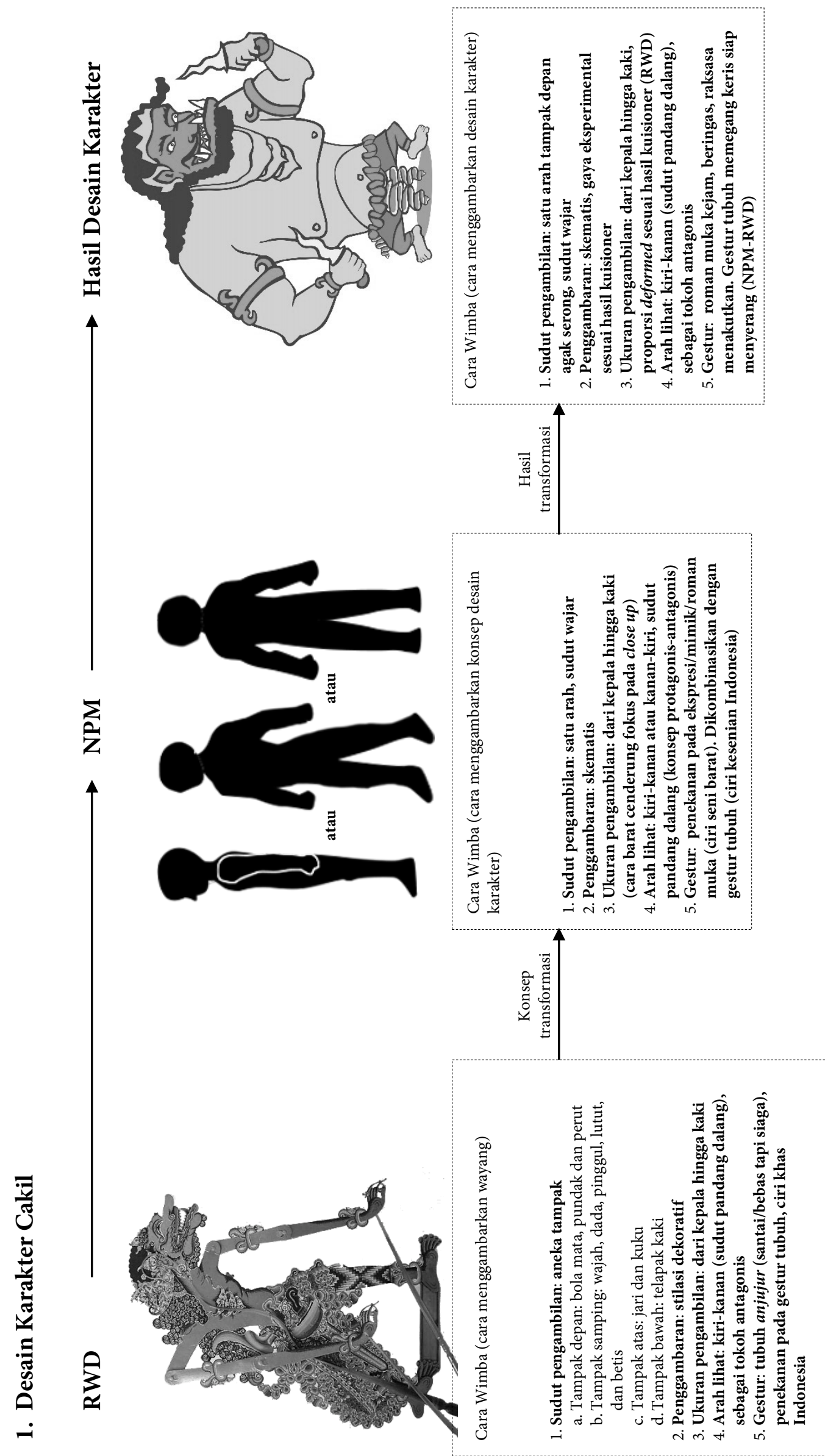




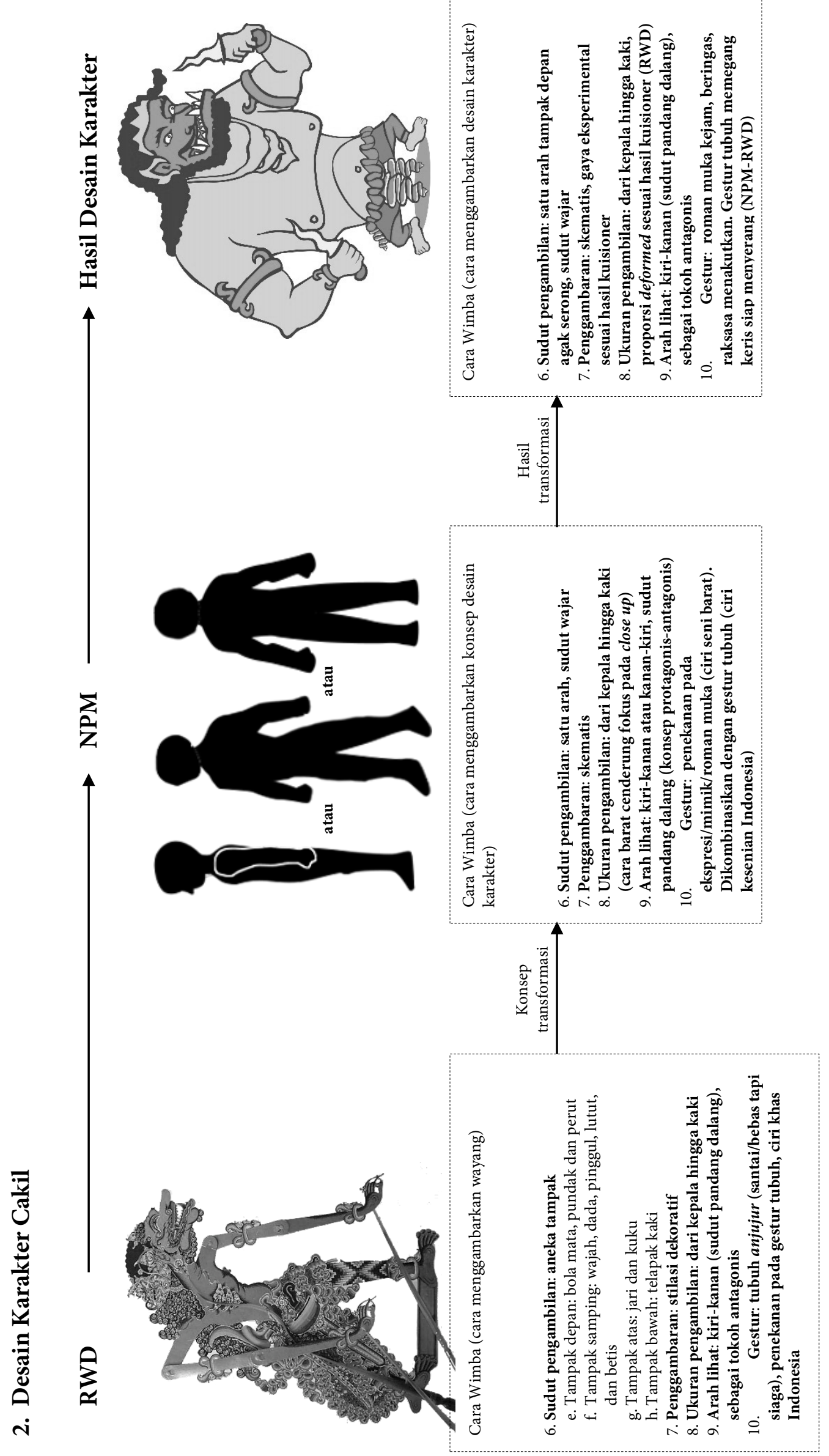




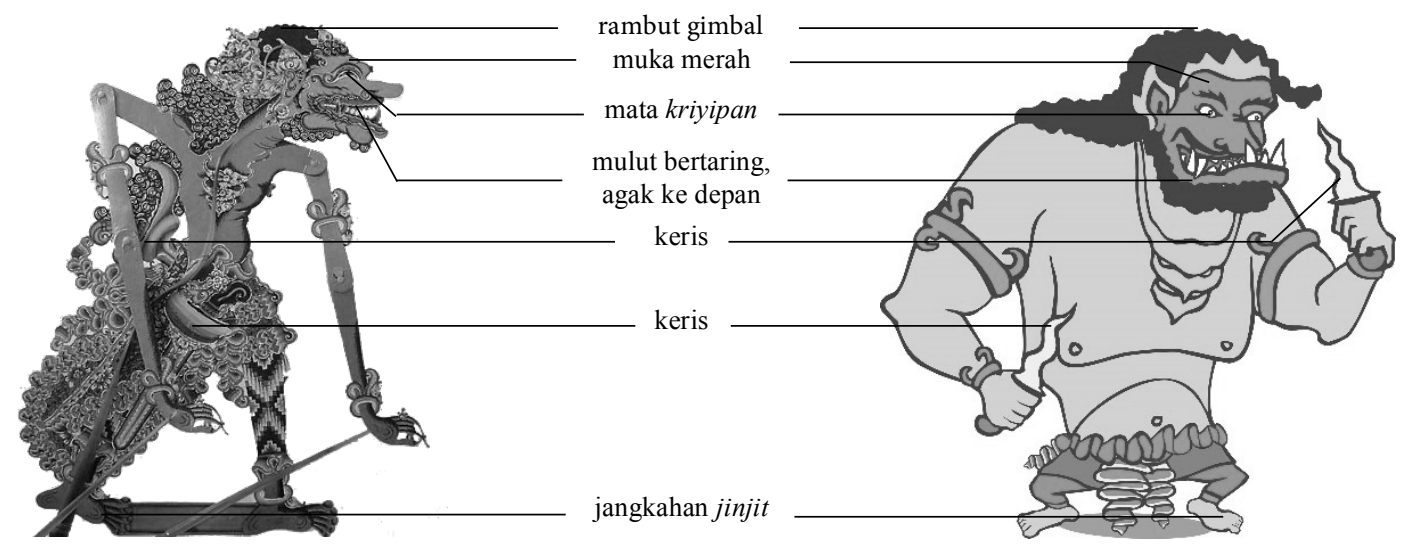

\section{Desain Karakter Bima}

Proses desain karakter Bima sama seperti proses desain karkater Cakil. Hanya saja terdapat perbedaan yakni arah lihat. Dari sudut pandang dalang, Cakil sebagai tokoh antagonis menghadap ke kanan, sedangkan Bima sebagai tokoh protagonis menghadap ke kiri.

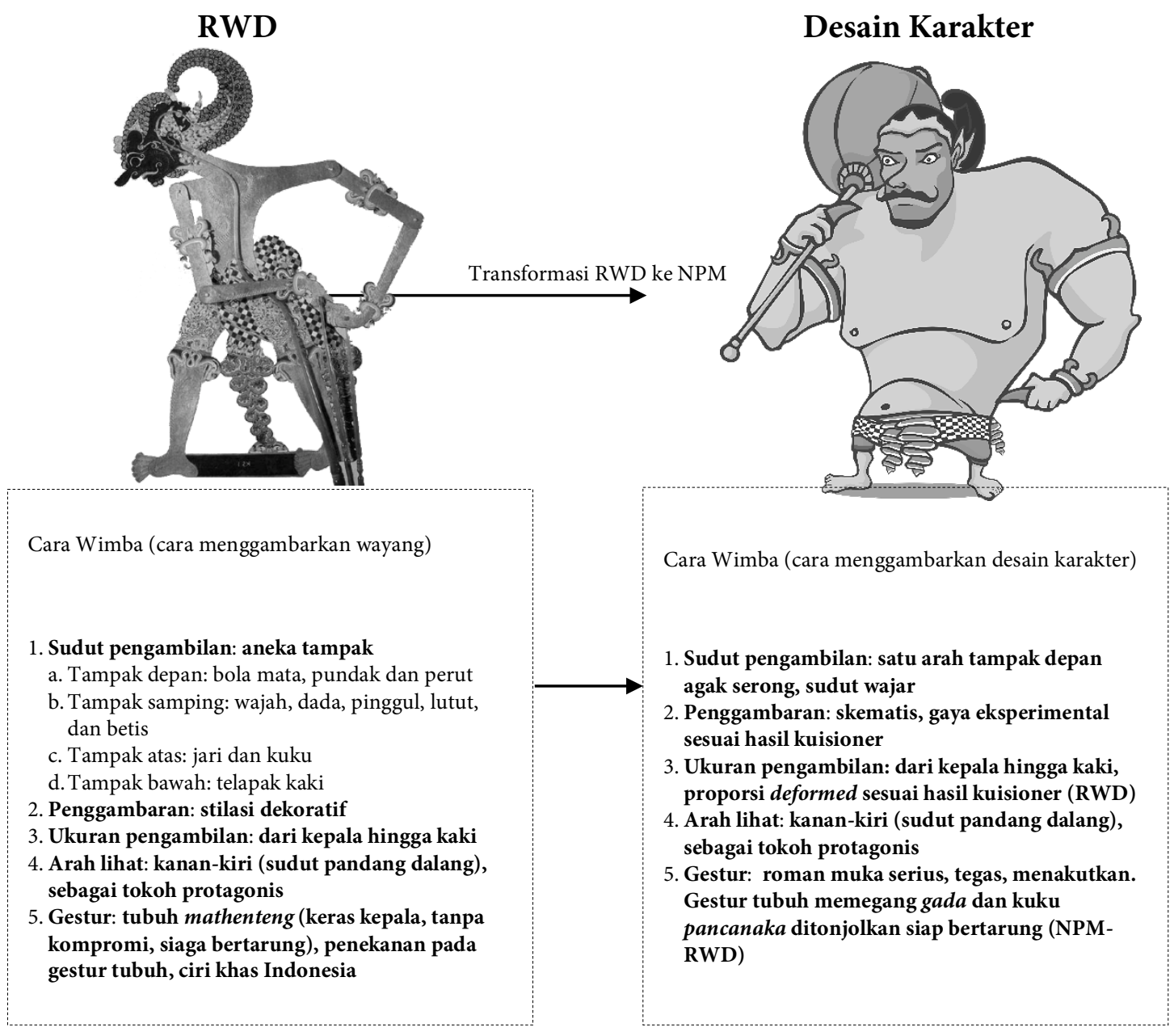




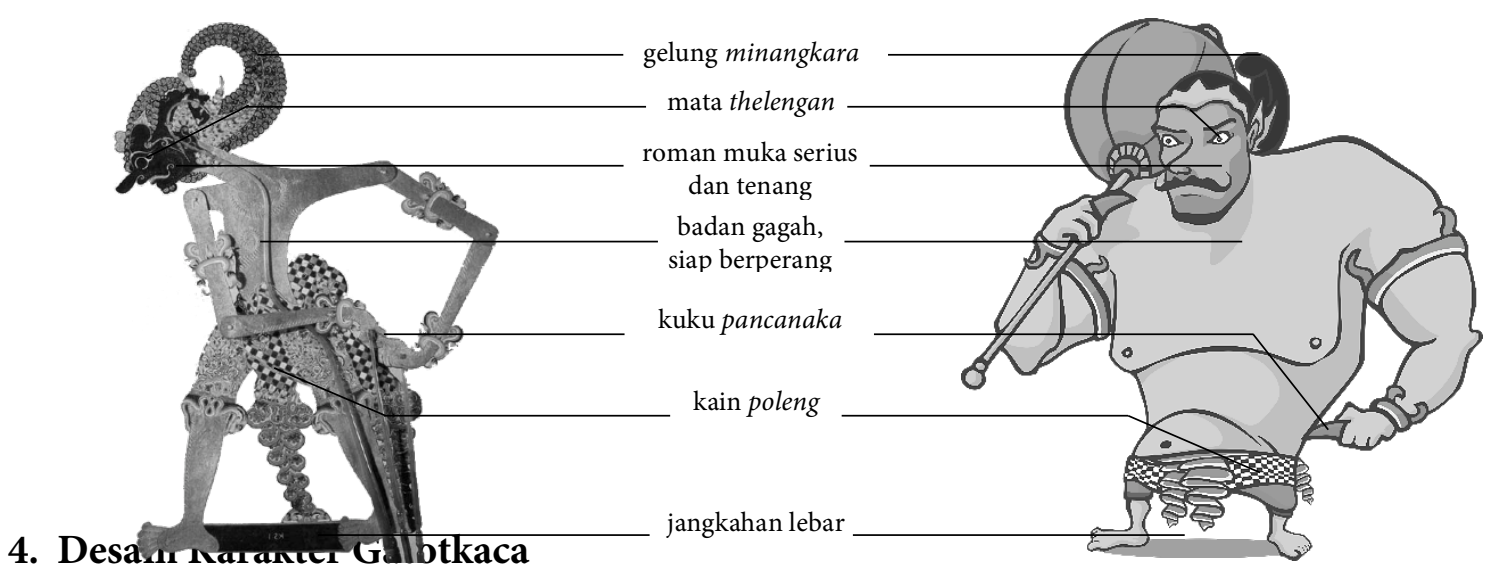

Secara visual, desain karakter Gatotkaca memiliki beberapa kemiripan dengan Bima wajah serius, dan tubuh gagah. Perbedaanya pada beberapa atribut busana dan senjata.

RWD

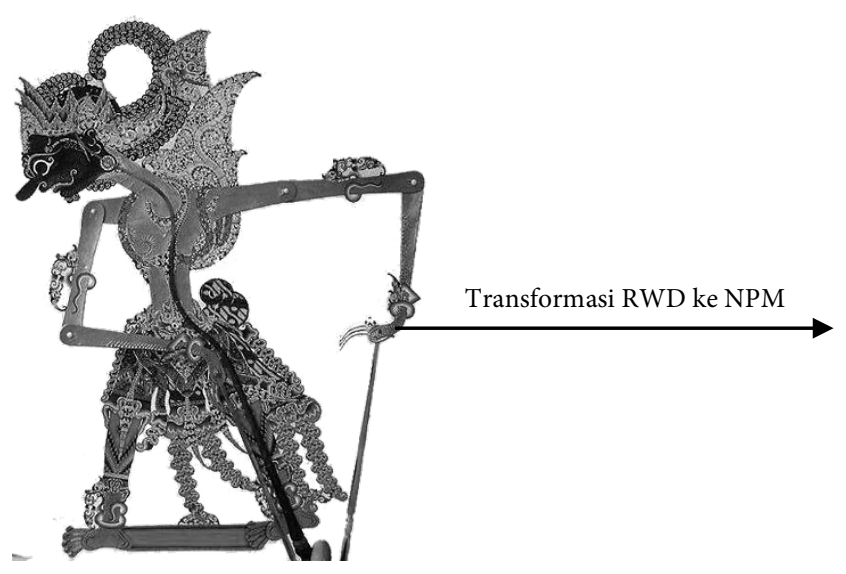

\section{Desain Karakter}

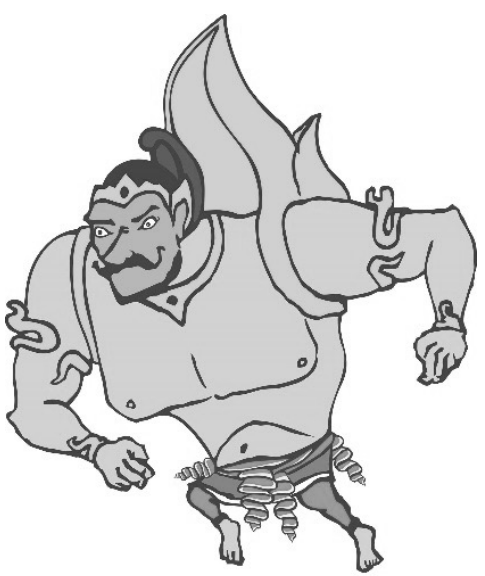

Cara Wimba (cara menggambarkan wayang)

1. Sudut pengambilan: aneka tampak

a. Tampak depan: bola mata, pundak dan perut

b. Tampak samping: wajah, dada, pinggul, lutut, dan betis

c. Tampak atas: jari dan kuku

d. Tampak bawah: telapak kaki

2. Penggambaran: stilasi dekoratif

3. Ukuran pengambilan: dari kepala hingga kaki

4. Arah lihat: kanan-kiri (sudut pandang dalang), sebagai tokoh protagonis

5. Gestur: tubuh malang kerik (sikap melawan, siap bertarung, posisi terbang), penekanan pada gestur tubuh, ciri khas Indonesia
Cara Wimba (cara menggambarkan desain karakter)

1. Sudut pengambilan: satu arah tampak depan agak serong, sudut wajar

2. Penggambaran: skematis, gaya eksperimental sesuai hasil kuisioner

3. Ukuran pengambilan: dari kepala hingga kaki, proporsi deformed sesuai hasil kuisioner (RWD)

4. Arah lihat: kanan-kiri (sudut pandang dalang), sebagai tokoh protagonis

5. Gestur: roman muka serius, tegas, menakutkan. Gestur tubuh hendak menyerang dan sedang terbang (NPM-RWD) 


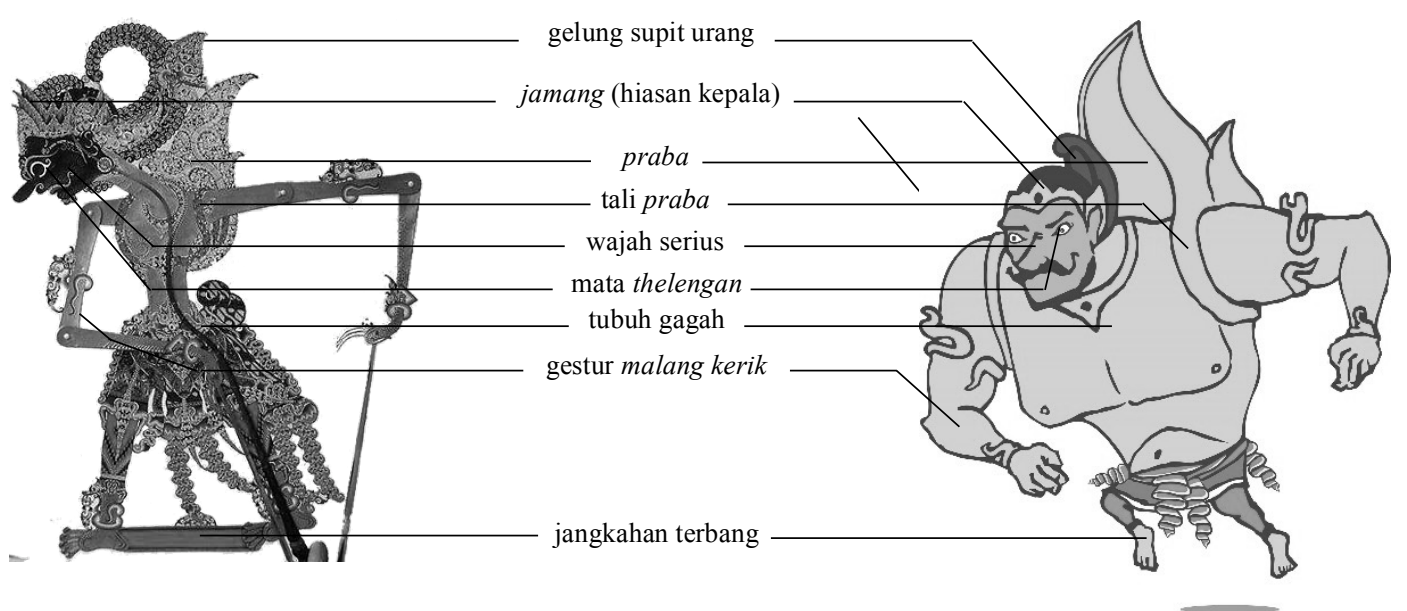

\section{Desain Karakter Petruk}

Petruk mewakili punakawan yang memiliki fisik sedikit berlainan, sesuai dengan peran tokoh dagelan dalam wayang yakni sebagai hiburan. Berbeda dengan desain karakter
Cakil, Bima, dan Gatotkaca, Petruk digambarkan lebih sederhana secara atribut menyesuaikan filosofi yang ada.
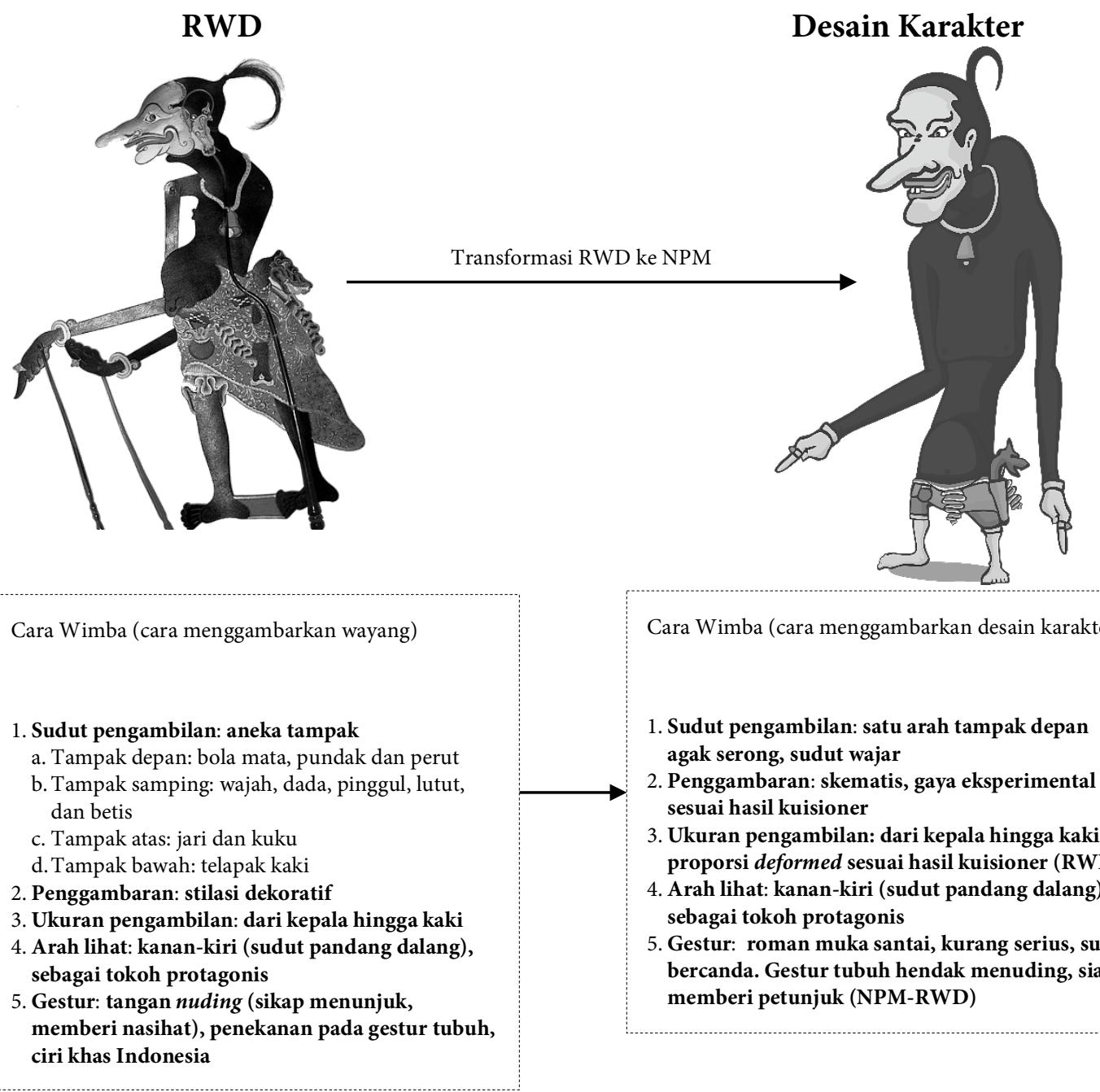

Cara Wimba (cara menggambarkan desain karakter)

1. Sudut pengambilan: satu arah tampak depan agak serong, sudut wajar

2. Penggambaran: skematis, gaya eksperimental sesuai hasil kuisioner

3. Ukuran pengambilan: dari kepala hingga kaki, proporsi deformed sesuai hasil kuisioner (RWD)

4. Arah lihat: kanan-kiri (sudut pandang dalang), sebagai tokoh protagonis

5. Gestur: roman muka santai, kurang serius, suka bercanda. Gestur tubuh hendak menuding, siap memberi petunjuk (NPM-RWD) 


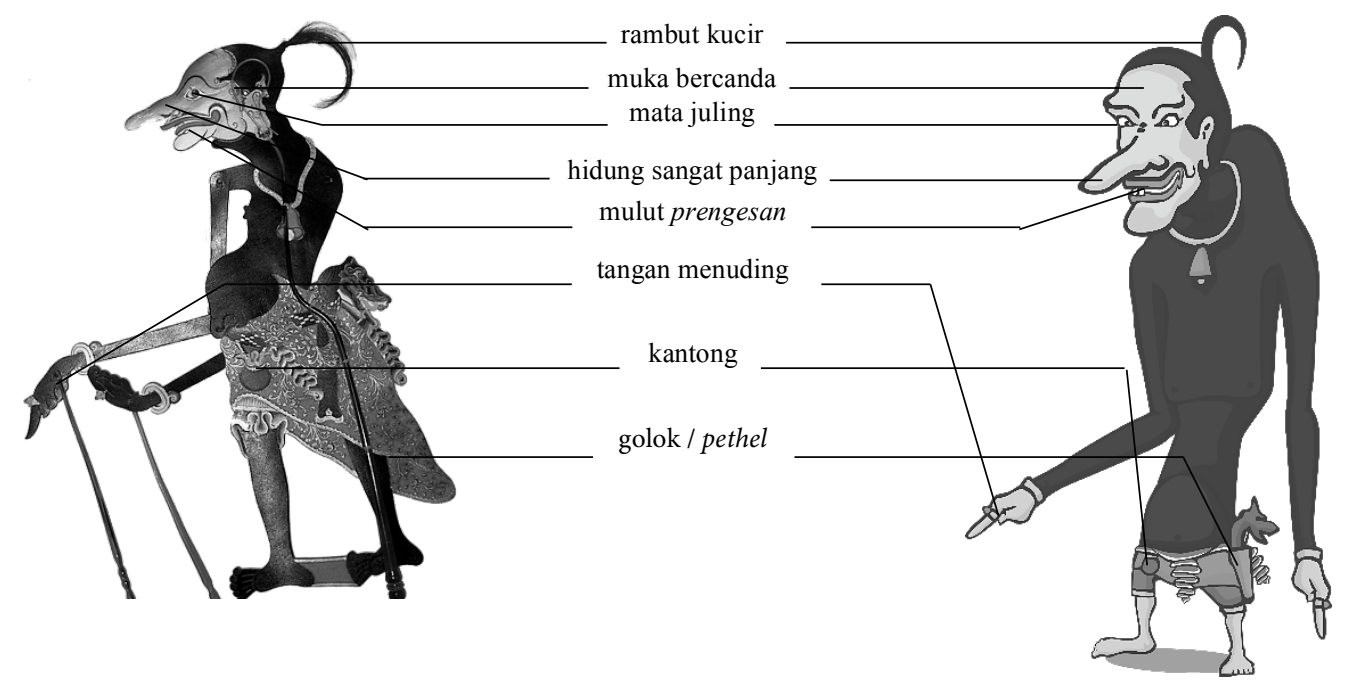

\section{PENUTUP}

Upaya revitalisasi kesenian wayang kulit ke dalam karya DKV merupakan langkah awal mempertahankan kebudayaan nasional. Adaptasi tokoh pewayangan ke dalam berbagai ragam karya DKV memberikan tambahan wawasan dan pengalaman bagi perancang maupun pelajar/mahasiswa. Hal ini menunjukkan bahwa wayang kulit purwa dengan segala keunikannya bisa berkolaborasi dengan perkembangan ilmu desain dan teknologi, yang tidak membatasi para peneliti untuk mengeksplorasi lebih jauh sesuai dengan latar belakang keilmuan masing-masing.

Perancangan model wujud visual tokoh pewayangan dalam pembentukan identitas dan watak tokoh sebagai acuan desain karakter dalam karya DKV merupakan langkah kecil untuk mengajak mahasiswa DKV dalam revitalisasi wayang kulit. Dengan hasil berupa model atau framework, penelitian ini diharapkan mampu menggugah semangat mahasiswa dalam berkarya dengan tema wayang. Penelitian ini lebih menekankan pada proses adaptasi tokoh wayang ke dalam desain karakter, sehingga fokus pada tahapan mulai dari pemilihan cerita/tokoh yang akan diadaptasi, breakdown elemen visual tokoh yang diadaptasi, transformasi bentuk dari bahasa rupa wayang RWD ke bahasa rupa desain karakter wayang NPM, yang dilanjutkan dengan evaluasi. Breakdown wujud visual wayang dilakukan guna menemukan identitas dan watak khas dari tokoh wayang. Transformasi RWD ke NPM gaya visual dan proporsi yang akan diterapkan dalam desain karakter. Sehingga karya yang dihasilkan tidak hanya memiliki nilai estetika, tetapi juga menyampaikan pesan sesuai dengan tokoh yang diangkat.

\section{DAFTAR PUSTAKA}

[1] Adi, F.N. (2014). Wayang dan Simbol Keluhuran Moyang. (Suara Merdeka) Retrieved February 06, 2015, from http://berita.suaramerdeka.com/wayan g-dan-simbol-keluhuran-moyangbagian-kedua/

[2] Aulan, B. M. (2013). Perancangan Ensiklopedia Digital Interaktif Tokoh Wayang Kulit Cirebon Pada Mobile Device. Tesis, Bandung: ITB

[3] Bastomi, S. (1995). Gemar Wayang. Semarang: Dahara Press. 
[4] Darmoko. (2004). Seni Gerak dalam Pertunjukan Wayang Tinjauan Estetika. Jurnal Sosial Humaniora, Vol 8[2], p 83-89. Depok: UI.

[5] Haryadi, T, et.al. (2013). Implementasi Teknik Sabetan Melalui Kinect (Studi Kasus Pengenalan Gerak Wayang Kulit Tokoh Pandawa). Jurnal TechnoCOM, Vol 12[1], p 51-64. Universtias Dian Nuswantoro: Semarang.

[6] Haryadi, T. (2013). Implementasi Teknik Sabetan Melalui Kinect (Studi Kasus Pengenalan Gerak Wayang Kulit Tokoh Pandawa). Tesis, Bandung: ITB

[7] Haryanto, S. (1991). Seni Kriya Wayang Kulit: Seni Rupa, Sunggingan dan Tatahan. Jakarta: Grafiti.

[8] Ismurdyahwati, dkk. (2007). Kajian Bahasa Rupa Berdasar Rekaman Video Pergelaran Wayang Kulit Purwa dalam Lakon 'Parta Krama'. Jurnal Wimba, Vol 1D[3], p 364-390. Bandung: ITB.

[9] Kepala Pusat Bahasa. (2008). Kamus Besar Bahasa Indonesia. DEPDIKNAS: Jakarta.

[10] Kuning, B. (2011). Atlas Tokoh-Tokoh Wayang dari Riwayat Sampai Silsilahnya. Yogyakarta: Narasi.
[11] Murtiyoso, B, dkk. (2004). Pertumbuhan dan Perkembangan Seni Pertunjukan Wayang. Surakarta: Citra Etnika.

[12] Pramana, M. et.al. (2007). Unsur Tasawuf dalam Perupaan Wayang Kulit Cirebon dan Surakarta. Jurnal Wimba, Vol 1D[2], p 181-195. Bandung: ITB.

[13] Pramana, M. I. (2007). Unsur Tasawuf dalam Perupaan Wayang Kulit Cirebon dan Surakarta. Tesis, Bandung: ITB.

[14] Purwadi. (2008). Seni Pedhalangan Wayang Purwa. Yokyakarta: Panji Pustaka.

[15] Soekatno. (1992). Mengenal Wayang Kulit Purwa: Klasifikasi, Jenis dan Sejarah. Semarang: Aneka Ilmu.

[16] Soetarno. (2010). Gaya Pedalangan Wayang Kulit Purwa Jawa. Jurnal Mudra, Vol 26[1], p 1-16. Surakarta: ISI.

[17] Susetya, W. (2007). Dhalang, Wayang dan Gamelan. Yogyakarta: Narasi.

[18] Tabrani, P. (2005). Bahasa Rupa. Bandung: Kelir.

[19] Tjandra, M. (2012). Perancangan Permainan Digital Kisah Dewa Ruci Sebagai Media Pengenalan Wayang Bagi Remaja. Tesis, Bandung: ITB. 